\title{
Activation of the hypoxia pathway in breast cancer tissue and patient survival are inversely associated with tumor ascorbate levels
}

Elizabeth J. Campbell ${ }^{1,2}$, Gabi U. Dachs ${ }^{1 \dagger}$, Helen R. Morrin ${ }^{1,3}$, Valerie C. Davey ${ }^{4}$, Bridget A. Robinson ${ }^{1,5}$ and Margreet C. M. Vissers ${ }^{2^{*}}$

\begin{abstract}
Background: The transcription factor hypoxia inducible factor (HIF) -1 drives tumor growth and metastasis and is associated with poor prognosis in breast cancer. Ascorbate can moderate HIF-1 activity in vitro and is associated with HIF pathway activation in a number of cancer types, but whether tissue ascorbate levels influence the HIF pathway in breast cancer is unknown. In this study we investigated the association between tumor ascorbate levels and HIF-1 activation and patient survival in human breast cancer.

Methods: In a retrospective analysis of human breast cancer tissue, we analysed primary tumor and adjacent uninvolved tissue from 52 women with invasive ductal carcinoma. We measured HIF-1a, HIF-1 gene targets CAIX, BNIP-3 and VEGF, and ascorbate content. Patient clinical outcomes were evaluated against these parameters.

Results: HIF-1 pathway proteins were upregulated in tumor tissue and increased HIF-1 activation was associated with higher tumor grade and stage, with increased vascular invasion and necrosis, and with decreased disease-free and disease-specific survival. Grade 1 tumors had higher ascorbate levels than did grade 2 or 3 tumors. Higher ascorbate levels were associated with less tumor necrosis, with lower HIF-1 pathway activity and with increased disease-free and disease-specific survival.

Conclusions: Our findings indicate that there is a direct correlation between intracellular ascorbate levels, activation of the HIF-1 pathway and patient survival in breast cancer. This is consistent with the known capacity of ascorbate to stimulate the activity of the regulatory HIF hydroxylases and suggests that optimisation of tumor ascorbate could have clinical benefit via modulation of the hypoxic response.
\end{abstract}

Keywords: Hypoxia-inducible factor-1, Ascorbate, Breast cancer, Disease-free survival

\section{Background}

The transcription factor, hypoxia-inducible factor (HIF)-1, is the master regulator for tumor adaptation to hypoxia generated by rapid cell growth and chaotic and fragile blood vessel networks [1-3]. HIF-1 upregulates many genes controlling glycolysis, intracellular $\mathrm{pH}$ (e.g. carbonic anhydrase IX [CA-IX]), angiogenesis (via vascular endothelial

\footnotetext{
* Correspondence: margreet.vissers@otago.ac.nz

Gabi U Dachs and Margreet CM Vissers contributed equally to project design, supervision, analysis of the data and manuscript preparation

${ }^{2}$ Centre for Free Radical Research, Department of Pathology and Biomedical

Science, University of Otago, Christchurch 8140, New Zealand

Full list of author information is available at the end of the article
}

growth factor [VEGF]) and cell life and death pathways (e.g. Bcl-2/adenovirus E1B $19 \mathrm{kDa}$ interacting protein 3 [BNIP-3]) [1-3]. Markers of HIF-1 activation are associated with increased tumor growth, resistance to chemotherapy and radiation, increased metastasis and poor prognosis, including in breast cancer. [2, 4-13]. Numerous studies have indicated a distinct survival advantage associated with reduced expression of HIF- $1 \alpha$, the regulatory subunit of HIF-1, in patients with breast cancer [5-9, 11-16].

HIF-1 activity is controlled by post-translational hydroxylation of HIF-1 $\alpha$; proline hydroxylation at P402 and P564 targets the protein for proteasomal degradation and

(c) The Author(s). 2019 Open Access This article is distributed under the terms of the Creative Commons Attribution 4.0 International License (http://creativecommons.org/licenses/by/4.0/), which permits unrestricted use, distribution, and reproduction in any medium, provided you give appropriate credit to the original author(s) and the source, provide a link to the Creative Commons license, and indicate if changes were made. The Creative Commons Public Domain Dedication waiver (http://creativecommons.org/publicdomain/zero/1.0/) applies to the data made available in this article, unless otherwise stated. 
hydroxylation of asparagine N803 prevents the formation of an active transcription complex [17-19]. The hydroxylases responsible for this regulation are Fe-containing 2-oxoglutarate-dependent dioxygenases (2-OGDDs) [20-22] that require 2-oxoglutarate and oxygen as substrates and $\mathrm{Fe}$ and ascorbate as cofactors. HIF- 1 is activated when hydroxylation of HIF- $1 \alpha$ is compromised [22-24].

Ascorbate levels influence HIF-1 activation [23, 25-27]. In cell culture, increased intracellular ascorbate decreases the extent of HIF-1 activation under conditions of mild-moderate hypoxia and metabolic disturbance similar to those seen in tumors $[25,28-31]$. In ascorbate-dependent $\mathrm{Gulo}^{-/-}$ knock-out mice, increased ascorbate availability reduced tumor growth, dampened HIF-1 activity, decreased areas of hypoxia and necrosis, and normalised tumor vasculature $[29,30,32]$. Retrospective analysis of human tumor tissue samples has revealed that increased ascorbate levels were associated with reduced HIF-1 pathway activity in endometrial [27], colorectal [26], papillary renal cell carcinoma [33] and thyroid tumor tissue [34], and with improved disease-free survival in colorectal cancer patients [26]. This data suggests that increased ascorbate availability dampens the tumor HIF-1 response and may mitigate the effects of tumor hypoxia. However, whether a similar relationship exists in breast cancer is unknown.

Breast cancer is the leading cause of cancer mortality for women [35]. HIF-1 is a major driver of breast cancer development and metastasis, and there is great interest in the potential to mitigate tumor hypoxia in this disease [2, 4-13]. Given previous findings, referred to above, that increasing cellular vitamin $\mathrm{C}$ content can moderate the hypoxic response, it is of interest to determine whether tumor ascorbate can influence the HIF-1 response in breast cancer.

There is some evidence from epidemiological studies that suggests that ascorbate intake could impact on breast cancer outcomes. Patient survival advantage with respect to ascorbate has been observed in a number of prospective observational studies that have monitored dietary vitamin $C$ intake [36-42]. These observations differ from other studies that suggest that multivitamin use (that includes vitamin C) is associated with increased risk of developing breast cancer [43, 44]. However, determining the effect of a single component in a multivitamin analysis is subject to error and it is unclear whether the effect observed in these studies is associated with vitamin $\mathrm{C}$. The most recent meta-analysis concluded that increased vitamin $\mathrm{C}$ intake is likely to be associated with a reduced risk of total and breast cancer-specific mortality [45]. However, none of these studies have measured ascorbate levels in either patient plasma or tumors, and there is no proposed mechanism of action to explain how increased ascorbate could impact on breast cancer progression and outcomes.
To determine whether tumor ascorbate levels vary in breast cancer and whether levels are associated with HIF-1 activation, we have undertaken a retrospective analysis of breast cancer tissues to quantify the ascorbate content in tumor and adjacent uninvolved breast tissue harvested from breast cancer patients at surgery. Ascorbate levels were related to the activation of the HIF-1 pathway, to patient survival, to tumor pathology, and the expression of the sodium dependent vitamin $\mathrm{C}$ transporter, SVCT-2. We hypothesise that tissue ascorbate levels are associated with HIF-1 pathway activity in breast cancer, and that low tumor ascorbate levels may have clinical implications.

\section{Methods \\ Materials}

MDA-MB-231 human breast cancer cells were from American Type Culture Collection, Cryosite Distribution, Australia. Anti- human HIF-1 $\alpha$, CA-IX, BNIP-3, and $\beta$-actin were from R\&D Systems, Minneapolis, USA; anti-human SVCT-2 was from Atlas Antibodies, Bromma, Sweden; anti-goat or anti-mouse HRP-conjugated antibodies were from DAKO, Australia. Pre-cast gels, buffers and solutions were from Invitrogen, Carlsbad, CA, USA, and all other chemicals from Sigma-Aldrich, St Louis, MO, USA. The VEGF DuoSet ELISA kit was from R\&D Systems, Minneapolis, USA.

\section{Ethical approval}

Ethical approval was granted by the University of Otago Human Ethics Committee, New Zealand (H15/093). Tissue samples were collected and approved for use by the Cancer Society Tissue Bank, Christchurch (CSTB) (Ethical Approval 16STH92 and P.15105). All donors gave written informed consent for sample collection, storage and use, along with access to their related clinical information. In addition, all experiments were performed in accordance to relevant guidelines and regulations. Ethnicity was self-reported, allowing multiple ethnic affiliations. A prioritized ethnic classification system was used and women were classified as Māori/Pacific if this was declared in any of their affiliations, otherwise ethnicity was classified as non-Māori/non-Pacific.

\section{Patient selection}

Tumor samples were included from patients who had undergone breast cancer surgery for invasive ductal carcinoma (IDC) at Christchurch hospital, New Zealand and become CSTB donors between 2002 and 2014. The patient cohort is an unselected group and there was no dietary or supplement intervention in this group. IDC tumors and paired normal tissue samples from 52 patients were selected to cover a range of grades and stages in both pre- and post-menopausal women. Tissue was 
taken from the same breast, with normal tissue taken at a distance of about $10 \mathrm{~cm}$ from the tumor. Most tumors contained both IDC and non-invasive ductal carcinoma in situ (DCIS). As per CSTB standard operating procedures, banked tissues were dissected and snap frozen in liquid nitrogen within an hour of surgical removal. The demographic and clinicopathological details (age, stage, grade, receptor status, nodal status, vascular invasion, necrosis) were from diagnostic pathology reports. Necrosis was only reported for the DCIS component of the tumor, as is standard.

\section{Follow-up and survival analysis}

Women with breast cancer were managed at Christchurch hospital according to nationally accepted guidelines. Patients at risk of local recurrence were referred for radiation, and those at risk of distant spread were referred for systemic adjuvant therapies (chemotherapy based on anthracyclines and taxanes). Women with receptor positive tumors were referred for appropriate treatment (endocrine treatment, trastuzumab), following international guidelines.

Patient follow up data was collated from the Breast Cancer Registry. Disease-free survival was calculated with the date of reported metastases or local recurrence as endpoint. Disease-specific mortality was calculated from the date of primary surgery to the date of death, with cause of death recorded as breast cancer.

\section{Sample preparation for ascorbate, cellular DNA and VEGF measurements}

Frozen tissue samples were homogenised into a fine powder in liquid nitrogen using a pre-cooled mortar and pestle, transferred into pre-weighed tubes and wet weight measured. Tumor homogenate $(10-100 \mathrm{mg})$ was resuspended in $200 \mu \mathrm{L}$ of phosphate buffer and used for ascorbate (160 $\mu \mathrm{L}$ aliquot), and DNA and VEGF analyses (40 $\mu \mathrm{L}$ aliquot).

\section{Ascorbate analysis}

Tissue ascorbate was measured using reverse-phase HPLC with electrochemical detection (Dionex Ultimate HPLC, with Dionex detector) [26, 27, 29]. Briefly, ascorbate in the tissue homogenate was stabilised by the addition of $1: 1$ volume of $0.54 \mathrm{M}$ perchloric acid containing $50 \mathrm{mM}$ diethylene triamine penta-acetic acid and the protein precipitate removed by centrifugation at $10,000 \mathrm{~g}$ for $10 \mathrm{~min}$. A standard curve of $1.25-40 \mu \mathrm{M}$ ascorbate was analysed with each run.

\section{Cellular DNA and VEGF analysis}

DNA content of the homogenate was measured with 1 $\mathrm{mg} / \mathrm{ml}$ propidium iodide and fluorescence measurement at $544-590 \mathrm{~nm}$ relative to a standard curve of purified calf thymus DNA [26]. Human VEGF was measured in the same homogenate using a DuoSet ELISA kit.

\section{Sample preparation for immunoblot analysis}

Due to the high fat content of the breast tissue, an optimised protein extraction procedure was developed. Homogenised tissue $(10-100 \mathrm{mg})$ was immediately immersed in $200 \mu \mathrm{L}$ of ice cold RIPA buffer $(150 \mathrm{mM} \mathrm{NaCl}, 1.0 \%$ IGEP $\mathrm{AL}^{\circ} \mathrm{CA}-630,0.5 \%$ sodium deoxycholate, $0.1 \% \mathrm{SDS}, 50 \mathrm{mM}$ Tris, pH 8.0 and containing complete mini protease inhibitors) on ice. Samples were further sheared by passing 5 times through a $21 \mathrm{G}$ needle and sonication for $\sim 30 \mathrm{~s}$. The homogenate was centrifuged at $10,000 \mathrm{~g}$ for $10 \mathrm{~min}$ at $4{ }^{\circ} \mathrm{C}$, the lipid layer removed with an insulin needle, the remaining sample was further sonicated and centrifuged at $10,000 \mathrm{~g}$ for $10 \mathrm{~min}$ at $4{ }^{\circ} \mathrm{C}$. The protein present in the final supernatant was precipitated with 9 volumes of ice-cold acetone on ice, collected by centrifugation at $2000 \mathrm{~g}$ for 10 min and resuspended in fresh RIPA buffer. The protein concentration was measured using the Direct Detect ${ }^{\circ}$ Spectrometer (Merck-Millipore, Germany).

\section{Immunoblot analysis}

Tumor and matched normal samples were standardized to $40 \mu \mathrm{g}$ of protein/ well, using $4 \mathrm{x}$ Bolt Laemmli buffer, containing dithiothreitol. Samples were separated by electrophoresis on a 4-12\% BisTris gradient SDS gel and transferred to polyvinylidene fluoride membrane. To allow normalization of the signal between Western blots, the same positive control (whole cell lysate harvested from MDA-MB-231 cells exposed to $1 \% \mathrm{O}_{2}$ ) was loaded onto each blot. Membranes were probed with antibodies against human HIF-1 $\alpha$ (1/800 dilution), CA-IX (1/800 dilution), BNIP-3 (1/1000) and $\beta$-actin (1/10000 dilution), and with secondary anti-goat or anti-mouse HRP-conjugated antibodies (1/10000). Blots were visualized with enhanced chemi-luminescence (ECL) reagent and bands quantified using Alliance software.

\section{HIF-1 pathway score}

Relative protein expression was obtained by normalising band density with respect to $\beta$-actin, and to a positive control (MDA-MB-231 cells exposed to $1 \% \mathrm{O}_{2}$ ) to control for exposure between blots. To obtain a HIF-1 pathway score for each tumor, the relative expression of each protein was determined as percent of the maximum expression, and the individual scores for HIF-1 $\alpha$, CA-IX, BNIP3 and VEGF were combined (HIF-1 pathway score $=$ HIF $-1 \alpha+$ CA9 + BNIP3 + VEGF). This approach provided a signature for the overall transcriptional activity of HIF-1 in each tumor. 


\section{Statistical analysis}

Data were analysed with SPSS and GraphPad Prism with the alpha level set at 0.05 . The Schapiro-Wilks normality test was used to determine the distribution of each variable. Normal vs tumor levels were compared using non-parametric Wilcoxon matched pairs signed rank. Associations between ascorbate and clinicopathological variables, or the HIF pathway, were assessed using Mann-Whitney or unpaired t-tests, for non-parametric and parametric data, respectively. Kaplan-Meier survival curves were analysed using Log rank (Mantel-Cox) test. Spearman's correlations were used to probe relationships between clinicopathological variables and ascorbate or the HIF pathway, and between tumor ascorbate and SVCT-2.

\section{Results}

\section{Description of patient cohort}

Tumors and adjacent normal breast tissue from women with primary infiltrating ductal carcinoma were included for analysis. Tumors were collected for tissue banking as part of routine treatment for breast cancer, and the patient group is unselected for any variations in fruit and vegetable or supplement intake. Most patients declared
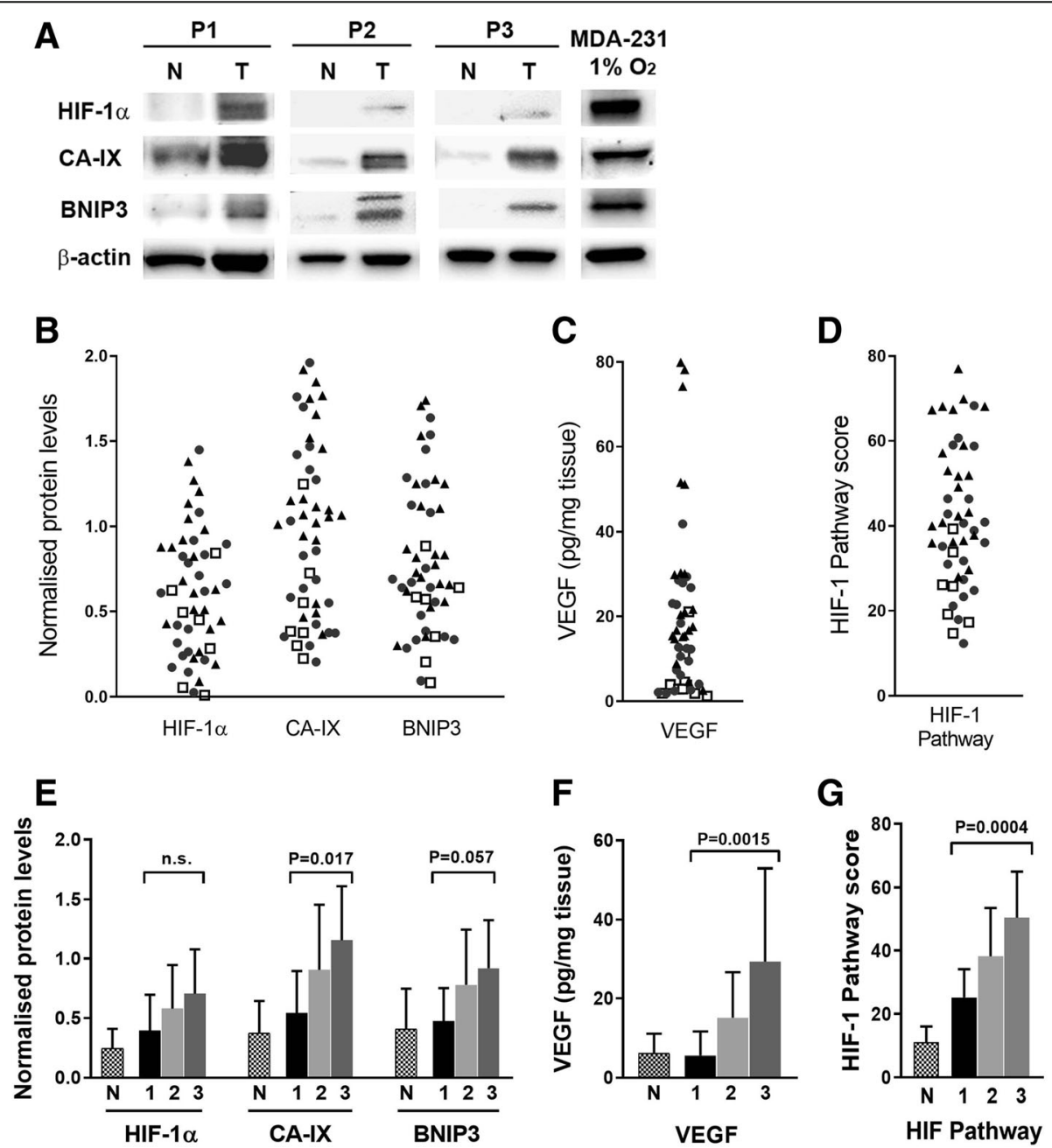

Fig. 1 Detection of HIF-1a and HIF-dependent proteins in human breast tumor tissue. VEGF was measured by ELISA and HIF-1a, CA-IX and BNIP3 were analysed in tumor and matching normal breast tissue by western blotting (a). For quantification of the proteins on western blots, band density was measured with ImageJ. Levels of individual proteins were normalised to the internal loading control, $\beta$-actin. A positive control (MDA-MB-231 cells exposed to $1 \% \mathrm{O}_{2}$ ) was loaded onto each gel to compare between blots and used to normalise development of protein bands between gels. The data in (a) are shown to exemplify the variable expression of HIF-1 pathway proteins in three individual patients (P1-P3) in tumor (T) and normal (N) tissue. Quantification was carried out with bands below saturation levels. b, c Relative expression of HIF-1a and downstream proteins for individual tumors are shown. Grade 1 () (n=9), Grade $2(\bullet)(n=20)$, Grade $3(\mathbf{\Delta})(n=22)$ tumors are indicated. The HIF Pathway score (d) for each tumor sample was derived by combining the individual scores for each protein from B and C, as follows: HIF-1 pathway score $=$ HIF-1 a + CA9 + BNIP3 + VEGF. e, f, g HIF-1 dependent proteins and HIF-1 Pathway score by tumor grade, showing means \pm S.D., and uninvolved tissue in comparison. Significant difference across the three grades was assessed by ANOVA 
themselves as non-Māori/non-Pacific (79\% European, $6 \%$ other or undeclared) with $15 \%$ Māori or Pacific, reflecting the ethnic makeup of the Canterbury region, New Zealand (stats.govt.nz). The median age of the cohort was 60 years, with $50 \%$ under 55 years and presumed to be pre-menopausal.

\section{Tissue banking procedures and storage}

The banking procedure is designed to minimise loss of tissue markers and all samples were snap frozen within an hour of surgery. We monitored for effect of handling and storage, and noted that the HIF- $1 \alpha$ protein content of both tumor and normal tissues did not vary over time $\left(R^{2}=0.0038\right.$ and 0.0152 , respectively) which ranged from 2 to 14 years at $-80^{\circ} \mathrm{C}$. We have previously demonstrated that ascorbate is stable in the tumor tissue during the banking procedure, and that there is no loss of tissue ascorbate upon extended storage at $-80^{\circ} \mathrm{C}$ [27].

\section{Hypoxia pathway in breast cancer tumors}

HIF- $1 \alpha$ protein was detected in 94\% (49/52) of tumor samples, and levels were significantly increased compared with the matched normal tissue sample $(p<0.001$, paired $\mathrm{t}$-test). Similarly, CA-IX, VEGF and BNIP3 levels were elevated in tumor compared to normal tissue, $(p<0.001, p<$ $0.001, p<0.001$ respectively, paired t-test) (Fig. 1a, e and f). Expression levels of each protein in the tumor samples covered a broad range, as illustrated in Fig. 1a, b, c and we noted a significant increase with tumor grade for each protein (Fig. 1e, f).

Use of the HIF-1 pathway score indicated associations with markers of tumor aggression, including grade $(p<$ $0.005)$, stage $(p=0.042)$, vascular invasion $(p=0.023)$ and DCIS necrosis $(p=0.001)$, as well as with invasive tumor size (Table 1). When individual scores for HIF- $1 \alpha$ or individual transcriptional marker proteins were considered, these associations were not significant (Fig. 1 and Table 1). Breast cancer subtypes could affect the expression of the HIF pathway proteins, as high levels of CA-IX expression have been reported in basal-like and triple negative breast cancers $[46,47]$. We noted increased levels of HIF- $1 \alpha$ in hormone receptor negative tumors $(p=0.02$, Table 1$)$, and CA-IX levels were also significantly higher in $\mathrm{HR}^{-}$, compared to $\mathrm{HR}^{+}$tumors (relative protein levels of $0.84 \pm 0.48$ and $1.44 \pm 0.38, P=$ $0.001, n=39$ and $n=10$, respectively). There was no difference in the range of expression of BNIP3 or VEGF between $\mathrm{HR}^{+}$and $\mathrm{HR}^{-}$tumors. These results combined for significantly higher HIF-1 pathway scores for the $\mathrm{HR}^{-}$tumors (Table 1 ).

\section{Impact of HIF-1 activation on patient survival}

The patient cohort was followed up for a median of 2400 days following surgery to record incidence of local

Table 1 Relationship of tumor HIF-1a protein levels and HIF-1 pathway score with clinicopathological parameters

\begin{tabular}{|c|c|c|c|c|c|c|}
\hline Parameter & & $\mathrm{n}$ & HIF-1a protein $^{a}$ & $p$ value & HIF-1 pathway score ${ }^{a, b}$ & $p$ value \\
\hline \multirow[t]{3}{*}{ Grade } & 1 & 7 & $0.39 \pm 0.30$ & 0.14 & $25.2 \pm 9.0$ & 0.004 \\
\hline & 2 & 20 & $0.58 \pm 0.37$ & & $38.2 \pm 15.3$ & \\
\hline & 3 & 22 & $0.70 \pm 0.37$ & & $50.5 \pm 14.5$ & \\
\hline \multirow[t]{3}{*}{ Tumor stage } & 1 & 16 & $0.59 \pm 0.45$ & 0.70 & $37.9 \pm 16.7$ & 0.042 \\
\hline & 2 & 31 & $0.60 \pm 0.33$ & & $42.2 \pm 15.6$ & \\
\hline & 3 & 2 & $0.83 \pm 0.31$ & & $68.7 \pm 1.8$ & \\
\hline \multirow[t]{2}{*}{ Node } & 0 & 17 & $0.53 \pm 0.33$ & 0.29 & $38.9 \pm 14.7$ & 0.37 \\
\hline & 1 & 32 & $0.65 \pm 0.39$ & & $43.4 \pm 17.5$ & \\
\hline \multirow[t]{3}{*}{ Vascular invasion } & 0 & 22 & $0.55 \pm 0.43$ & 0.28 & $36.5 \pm 16.2$ & 0.023 \\
\hline & 1 & 26 & $0.67 \pm 0.32$ & & $47.2 \pm 15.3$ & \\
\hline & na & 1 & & & & \\
\hline \multirow[t]{3}{*}{ DCIS Necrosis } & 0 & 17 & $0.49 \pm 0.31$ & 0.14 & $31.5 \pm 11.1$ & 0.001 \\
\hline & 1 & 27 & $0.65 \pm 0.35$ & & $47.0 \pm 15.8$ & \\
\hline & na & 5 & & & & \\
\hline Tumor size ${ }^{c}$ & Pearson correlation & 49 & $R=0.101$ & 0.49 & $R=0.348$ & 0.014 \\
\hline \multirow[t]{2}{*}{ Hormone Receptor Status ${ }^{d}$} & $\mathrm{HR}^{+}$ & 39 & $0.55 \pm 0.34$ & 0.02 & $38.1 \pm 15.3$ & 0.001 \\
\hline & $\mathrm{HR}^{-}$ & 10 & $0.85 \pm 0.40$ & & $56.6 \pm 13.0$ & \\
\hline
\end{tabular}

${ }^{a}$ Mean \pm SD from $n=49$ patients, $p$ values from ANOVA. Significance is indicated when $p<0.05$

${ }^{b}$ HIF-1 pathway score calculated from relative protein levels of HIF-1a, CA-IX, BNIP-3 and VEGF

na, not available

'Tumor size, invasive component only, excluding DCIS

${ }^{\mathrm{d}}$ Hormone receptor $\mathrm{HR}^{+}, \mathrm{ER}+\left(\mathrm{PR}+/-\right.$, Her2+/-) and includes both Luminal A and B; HR ${ }^{-}$, ER-PR-(Her2+/-) and includes Her2-enriched and basal-like tumours 
recurrence or metastasis, or death from breast cancer. During follow-up, 14 patients recorded metastases (mainly to bone and lung), one recorded a local recurrence, and 13 patients died from breast cancer. Tumor HIF-1 $\alpha$ protein levels were associated with 10-year disease-specific survival $(P=0.035)$ but not with disease-free survival $(P=0.451)$ (Fig. 2$)$. In comparison, increased HIF Pathway scores were associated with a marked reduction for both disease-free $(P=0.014)$ and disease-specific patient survival $(P=0.004$, Fig. 2$)$.

\section{Ascorbate levels in tumor and normal tissue and relationship with clinicopathological features}

Tissue ascorbate levels were related to DNA content to standardise for the cellular content of tumor or normal tissue. This was particularly important due to the variation caused by the high fat content and correspondingly low cell number per gram of human breast tissue. Tumor tissue contained less fat than normal breast tissue, reflecting a fundamental difference in the cellular composition of the tumor and normal breast. For tumor tissue, but not normal tissue, ascorbate standardised to DNA was significantly correlated to ascorbate per tissue wet weight (Pearson $r=0.321, P=0.023$ ). Of 52 tumor samples, 50 provided ascorbate data (96\%).

Tumor ascorbate levels were similar to those in normal breast tissue (Fig. 3a), but there was no correlation between tumor and normal tissue levels in individual patients (Pearson $r=-0.06, P=0.69$, Fig. 3b). Both tumor and normal tissue showed a considerable range in ascorbate levels (95\% CI $0.136-0.222$ and $0.086-0.342 \mathrm{nmol} /$ $\mu \mathrm{g}$ DNA, respectively).

To probe the associations of ascorbate content with patient and tumor characteristics, the cohort was stratified for levels above and below the mean, $0.2 \mathrm{nmol}$ ascorbate/ $\mu \mathrm{g}$ DNA (Table 2). Ascorbate levels were generally higher in grade 1 than in grade 2 or 3 tumors $(P=0.007$, Fig. $3 c$ and Table 2). There was no relationship with tumor stage or tumor size (Table 2), but tumors with DCIS necrosis had lower mean ascorbate content compared with those without necrosis $(P<0.01$, Fig. $3 \mathrm{~d})$. There was no significant difference in the ascorbate levels according to hormone receptor status (Table 2).

\section{Association of tumor ascorbate with the HIF pathway}

The levels of HIF-1 $\alpha$ and HIF-1 target proteins were compared between tumors with below or above mean

\section{Disease-Free Survival}
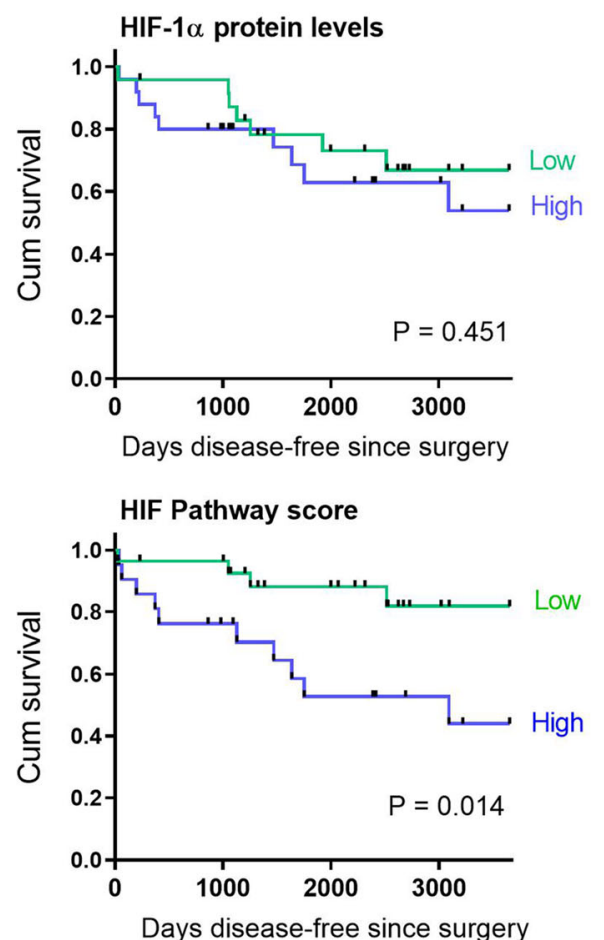

\section{Disease-Specific survival}
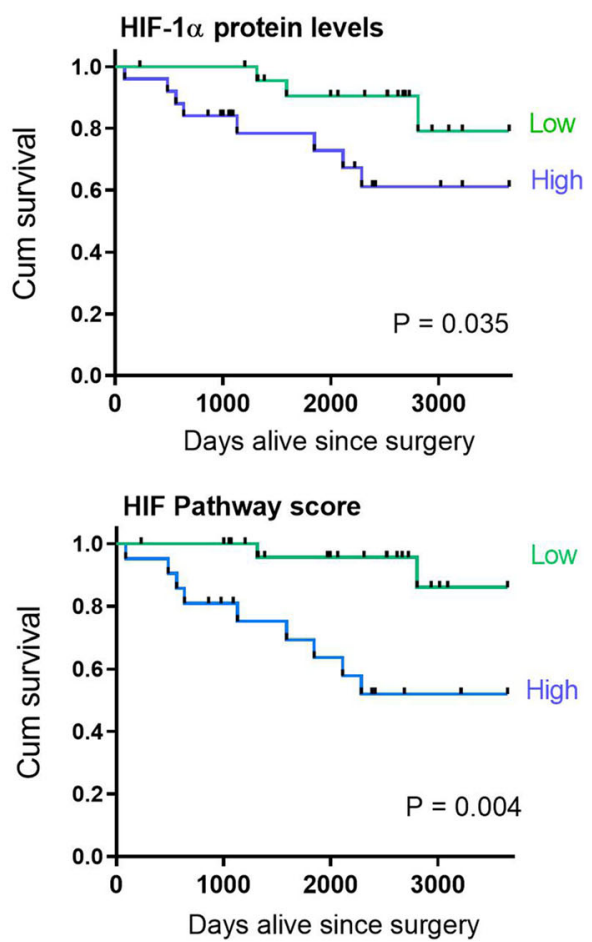

Fig. 2 Patient disease-free and disease-specific 10 year survival associated with HIF-1a protein expression or HIF-Pathway score. Kaplan-Meier plots with above and below the mean levels of HIF-1a or the mean of the HIF Pathway score. Patient numbers in each group: high HIF-1a, $n=25$; low HIF-1a, $n=24$; low HIF Pathway, $n=28$; high HIF Pathway, $n=21$. Significant difference was determined by log-rank (Mantel Cox) analysis 

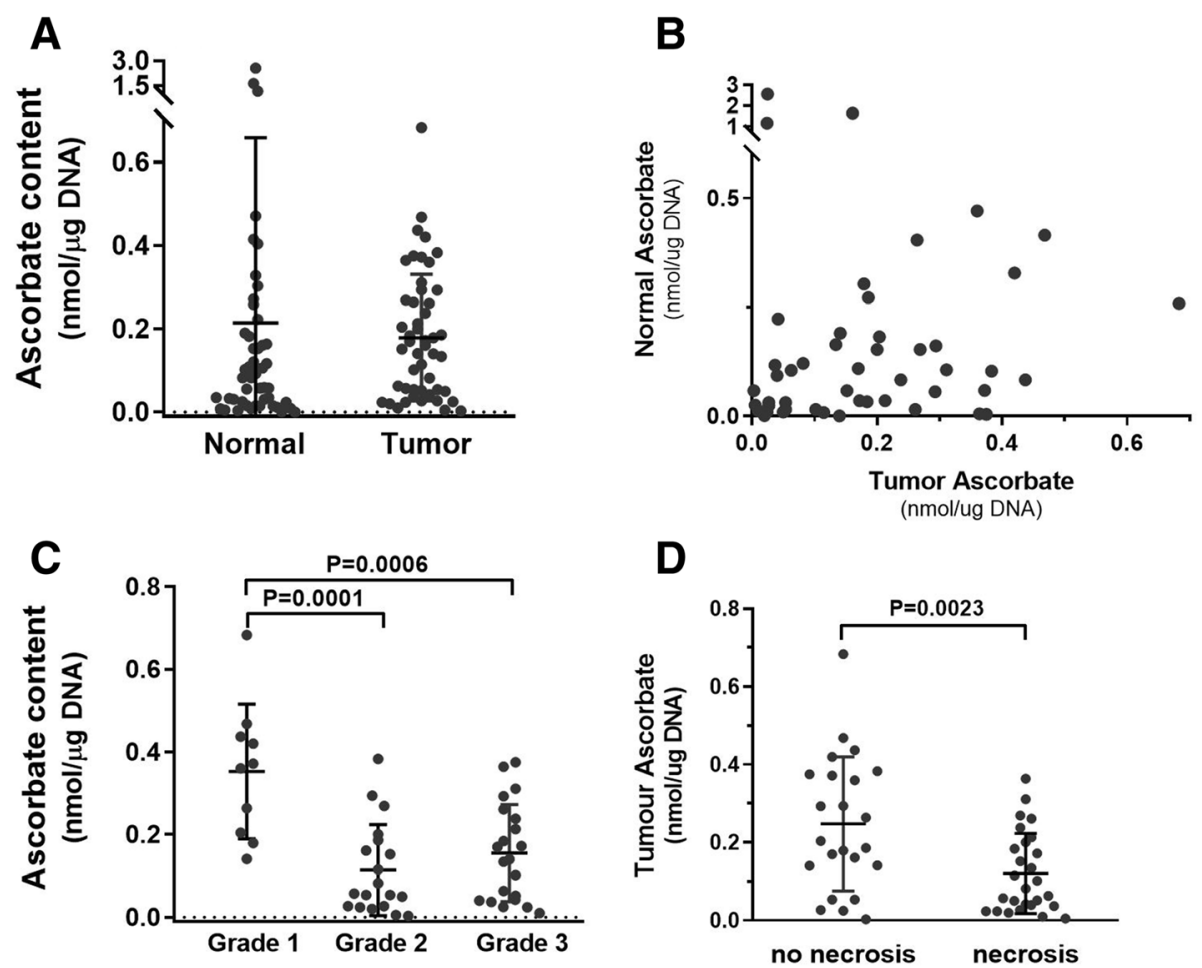

Fig. 3 Ascorbate levels in breast tumor tissue and adjacent normal tissue. a There was no difference in the range of levels of ascorbate measured in tumor or normal breast tissue samples. $\mathbf{b}$ There was no association between tumor $(n=49)$ and normal $(n=49)$ breast tissue ascorbate levels. $\mathbf{c}$ Ascorbate levels were significantly lower in grade $2(n=20)$ or $3(n=22)$ tumors than in grade $1(n=9)$. $\mathbf{d}$ Ascorbate levels were lower in tumors with necrosis $(n=27)$ than in those without $(n=23)$. Means \pm S.D. are shown

ascorbate levels (Fig. 4). HIF-1 $\alpha$ protein and CA-IX levels were significantly higher in tumors containing below mean ascorbate $(P=0.032$ and 0.05 respectively, Fig. 4). A similar trend was observed for BNIP3 $(P=0.057)$, whereas VEGF showed little association $(P=0.217)$. There was a strong association between tumor ascorbate and overall HIF-1 activation, with a significantly higher HIF Pathway score in those samples with ascorbate levels below the mean $(P=0.007)$. Tumor ascorbate levels were not related to the expression of the ascorbate transporter SVCT2 (Fig. 4).

\section{Patient survival according to tumor ascorbate and HIF-1 levels}

There was no significant difference in disease-free survival or disease-specific survival according to mean tumor ascorbate levels ( $P=0.172$ and 0.322 , respectively) (Table 3$)$. To determine whether high tumor ascorbate content could contribute to improved survival via the HIF-1 pathway, as suggested by the results in Figs. 2 and 4, and to allow comparison between low and high ascorbate levels, we plotted Kaplan Meier survival curves for the population by ascorbate content, with the tumor ascorbate levels stratified into thirds $(<0.13 \mathrm{nmol} / \mu \mathrm{g}$ DNA; $0.13-0.26 \mathrm{nmol} / \mu \mathrm{g}$ DNA; > $0.26 \mathrm{nmol} / \mu \mathrm{g}$ DNA). As shown in Fig. 5, patient disease-free survival $(P=0.047)$ and disease-specific survival $(P=0.022)$ improved significantly with increasing tumor ascorbate levels. The difference was noted across the range, and also for those patients with the highest tumor ascorbate levels compared with the lowest group ( $P$ $=0.046$ and 0.021 for disease-free and disease-specific survival, respectively).

\section{Discussion}

Our retrospective analysis of human breast cancer tissue demonstrates a close association between activation of the HIF-1 transcription factor and patient survival. There was a greater difference in disease progression and breast cancer survival when the HIF Pathway score was used than when HIF-1 $\alpha$ protein was considered, supporting the use of the pathway score as a robust marker of HIF-1 transcriptional activity and, potentially, patient prognosis. Most other studies that have monitored hypoxia markers used a single protein marker of HIF-1 activation [5-9, 11-16]. We found that the tumor grade, stage, size, vascular invasion, and necrosis were also associated with a high HIF Pathway score, but not with HIF-1 $\alpha$ alone. This data supports the use of a HIF-1 signature that combines measures of HIF- $1 \alpha$ and downstream genes and highlights the usefulness of the 
Table 2 Relationship of ascorbate levels in tumors with clinicopathological and patient parameters

\begin{tabular}{|c|c|c|c|c|}
\hline \multirow[t]{2}{*}{ Parameter } & & \multicolumn{3}{|c|}{ Ascorbate in tumor tissue $e^{a}$} \\
\hline & & $<$ mean & $>$ mean & $p$ value $^{\mathrm{e}}$ \\
\hline \multirow[t]{3}{*}{ Ethnicity } & Maori/Pacific & 7 & 1 & 0.099 \\
\hline & non-Maori/non-Pacific & 23 & 18 & \\
\hline & undeclared & 1 & 0 & \\
\hline \multirow[t]{2}{*}{ Age } & $<55$ year & 16 & 9 & 0.500 \\
\hline & $>55$ years & 15 & 10 & \\
\hline \multirow[t]{3}{*}{ Grade } & 1 & 2 & 8 & 0.007 \\
\hline & 2 & 15 & 4 & \\
\hline & 3 & 14 & 7 & \\
\hline \multirow[t]{3}{*}{ Tumor Stage } & 1 & 11 & 5 & 0.769 \\
\hline & 2 & 19 & 13 & \\
\hline & 3 & 1 & 1 & \\
\hline \multirow[t]{3}{*}{ Nottingham $^{\mathrm{b}}$} & $\leq 3.4$ & 4 & 5 & 0.370 \\
\hline & $3.41-5.4$ & 14 & 9 & \\
\hline & $>5.4$ & 13 & 5 & \\
\hline \multirow[t]{2}{*}{ Node } & negative & 11 & 5 & 0.500 \\
\hline & positive & 20 & 14 & \\
\hline \multirow[t]{3}{*}{ Vascular invasion } & no & 13 & 10 & 0.357 \\
\hline & yes & 18 & 8 & \\
\hline & unknown & & 1 & \\
\hline \multirow[t]{2}{*}{ Tumor size ${ }^{c}$} & $\leq 2 \mathrm{~cm}$ & 12 & 5 & 0.369 \\
\hline & $>2 \mathrm{~cm}$ & 19 & 14 & \\
\hline \multirow[t]{3}{*}{ DCIS Necrosis } & no & 8 & 9 & 0.055 \\
\hline & yes & 19 & 6 & \\
\hline & unknown & 4 & 4 & \\
\hline \multirow[t]{2}{*}{ Hormone Receptor status ${ }^{d}$} & $\mathrm{HR}+$ & 24 & 17 & 0.452 \\
\hline & HR- & 7 & 2 & \\
\hline
\end{tabular}

${ }^{a}$ Number of patients below $(n=31)$ or above $(n=19)$ the mean ascorbate level of $0.2 \mathrm{nmol} / \mu \mathrm{g}$ DNA in tumor tissue

${ }^{b}$ Nottingham prognostic index: calculated from tumor size, number of involved lymph nodes and tumor grade [73], with good, moderate and poor prognosis [74].

'Tumor size, invasive component only, excluding DCIS

${ }^{\mathrm{d} H o r m o n e}$ receptor $\mathrm{HR}^{+}, \mathrm{ER}+(\mathrm{PR}+/-, \mathrm{Her} 2+/-)$ and includes both Luminal A and B; HR ${ }^{-}$, ER-PR-(Her2+/-) and includes Her2-enriched and basal-like tumours

${ }^{\mathrm{e}} \mathrm{Chi}$-square or Fisher's exact test, as appropriate. Significance is indicated when $p<0.05$

HIF Pathway when monitoring the impact of transcriptional activity. Similarly, a HIF-1 expression signature of 16 genes was shown to be more tightly associated with patient survival from breast cancer than was the expression of HIF-1 $\alpha$ alone [48]. Together, these observations reflect the prevalence of HIF-1 transcriptional activity in breast cancer and underscore the clinical interest in modulating this response to improve chemotherapy response and decrease metastasis.

There is some evidence that breast cancer sub-types may be differentially affected by HIF-1. One study has shown that HIF-1 preferentially stimulates cancer stem differentiation in ER+ but not ER- breast cancer cells [49]. We also noted significant difference in HIF-1 $\alpha$ protein and HIF-1 pathway score between hormone receptor positive and negative tumors. The $\mathrm{HR}+$ group includes both Luminal A and B sub-types, whereas the HR- group includes Her2-enriched and basal-like tumours [50]. However, we saw no difference in ascorbate levels according to HR status.

Elevated tumor ascorbate was associated with decreased expression of HIF- $1 \alpha$ protein and downstream genes, and was strongly associated with a low HIF Pathway score, suggestive of an overall effect of ascorbate on HIF-1 activation. It is highly likely that this association reflects activity of ascorbate as a co-factor for the HIF hydroxylases. Although we are unable to test this directly in our retrospective tumor tissue analysis, this effect has been documented in in vitro studies where low intracellular ascorbate levels exacerbate HIF-1 activation in response to moderate hypoxia $[25,30]$ by affecting the proline and aspargine hydroxylases [25, 51]. Our 

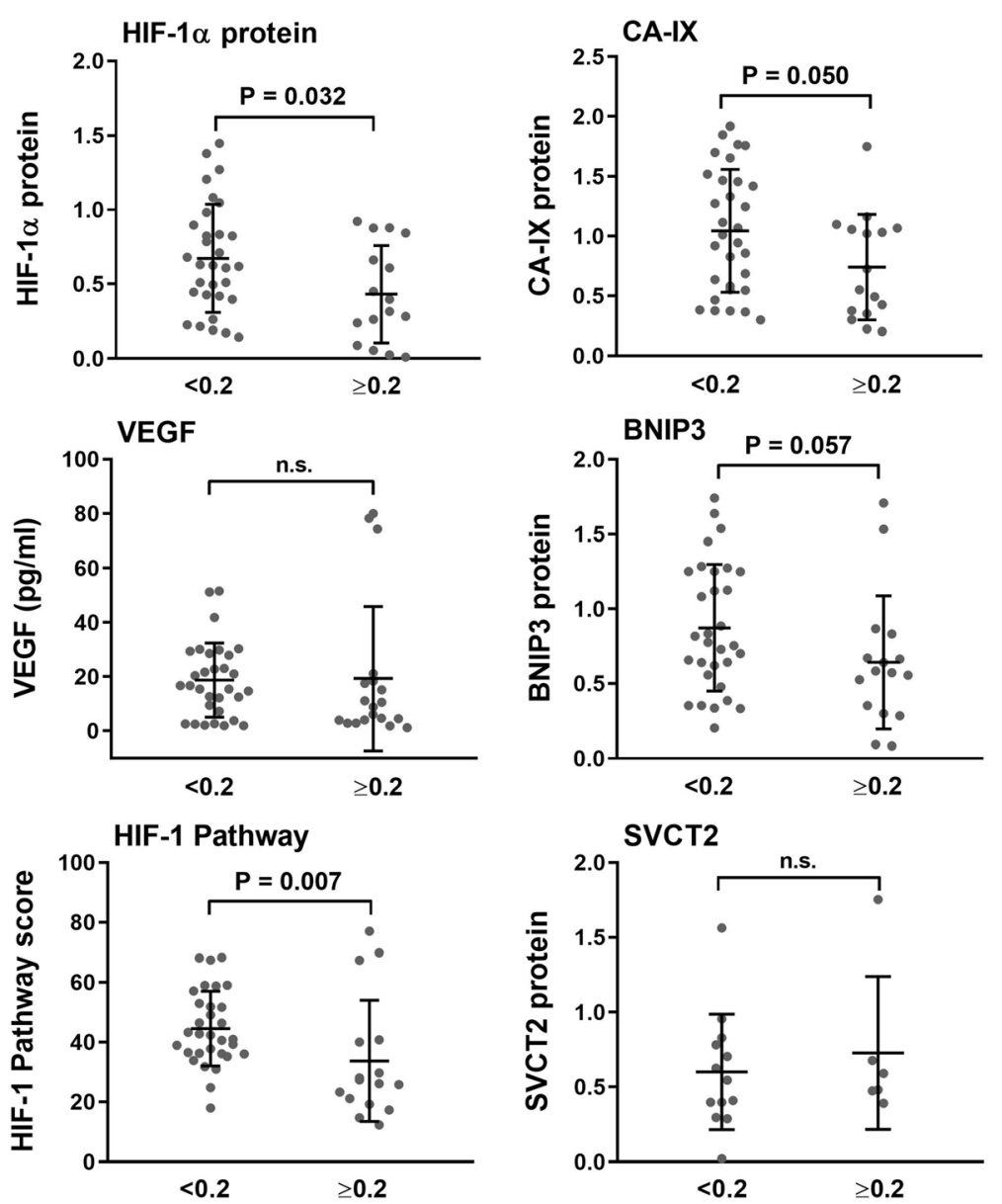

Ascorbate (nmol/ $\mu \mathrm{g}$ DNA)

Ascorbate (nmol/ $\mu \mathrm{g}$ DNA)

Fig. 4 Relationship between tumor ascorbate and expression of the HIF-1 pathway proteins and SVCT2. Levels of HIF-1a, CAIX, VEGF and BNIP3 were stratified according to the mean tumor ascorbate level $<0.2 \mathrm{nmol} / \mu \mathrm{g}$ DNA $(n=31),>0.2 \mathrm{nmol} / \mu \mathrm{g}$ DNA $(n=16)$. HIF-1a, CAIX, VEGF and BNIP3 were generally higher in tumor tissue with low ascorbate, culminating in a significant relationship between higher ascorbate levels and a low HIF Pathway score. Means \pm S.D. are shown. Statistical significance was determined with an unpaired t-test (HIF-1a, CA-IX) or the Mann Whitney test for non-parametric data (VEGF, BNIP3, HIF Pathway, SVCT-2). SVCT-2 below the mean $n=13$, above the mean $n=6$

Table 3 Survival of breast cancer patients according to mean tumor ascorbate or HIF-1 pathway score

\begin{tabular}{|c|c|c|c|c|c|}
\hline & & \multicolumn{2}{|c|}{ Tumor ascorbate ${ }^{a}$} & \multicolumn{2}{|c|}{ HIF-1 pathway score ${ }^{a}$} \\
\hline & & $<$ mean & $\geq$ mean & $<$ mean & $\geq$ mean \\
\hline \multirow[t]{4}{*}{ Disease-free survival } & Mean days & 2772 & 3613 & 3865 & 2412 \\
\hline & $95 \% \mathrm{Cl}$ & $(2142,3402)$ & $(3022,4204)$ & $(3286,4443)$ & $(1787,3037)$ \\
\hline & No. events & 10 & 4 & 3 & 11 \\
\hline & $p$ value & 0.173 & & 0.01 & \\
\hline \multirow[t]{4}{*}{ Disease-specific survival } & Mean days & 2977 & 3613 & 4216 & 2439 \\
\hline & $95 \% \mathrm{Cl}$ & $(2350,3603)$ & $(3022,4204)$ & $(3834,4598)$ & $(1824,3054)$ \\
\hline & No. events & 8 & 4 & 1 & 11 \\
\hline & $p$ value & 0.322 & & 0.001 & \\
\hline
\end{tabular}

${ }^{a}$ Tumor ascorbate mean: $0.2 \mathrm{nmol} / \mu \mathrm{g}$ DNA, $n=31$ below the mean, $n=19$ above the mean; Tumor HIF-1 pathway score median: 41.8 (HIF-1 pathway score calculated from relative protein levels of HIF-1a, CA-IX, BNIP-3 and VEGF); $n=28$ below and $n=21$ above the mean. Significance is indicated when $p<0.05$ 

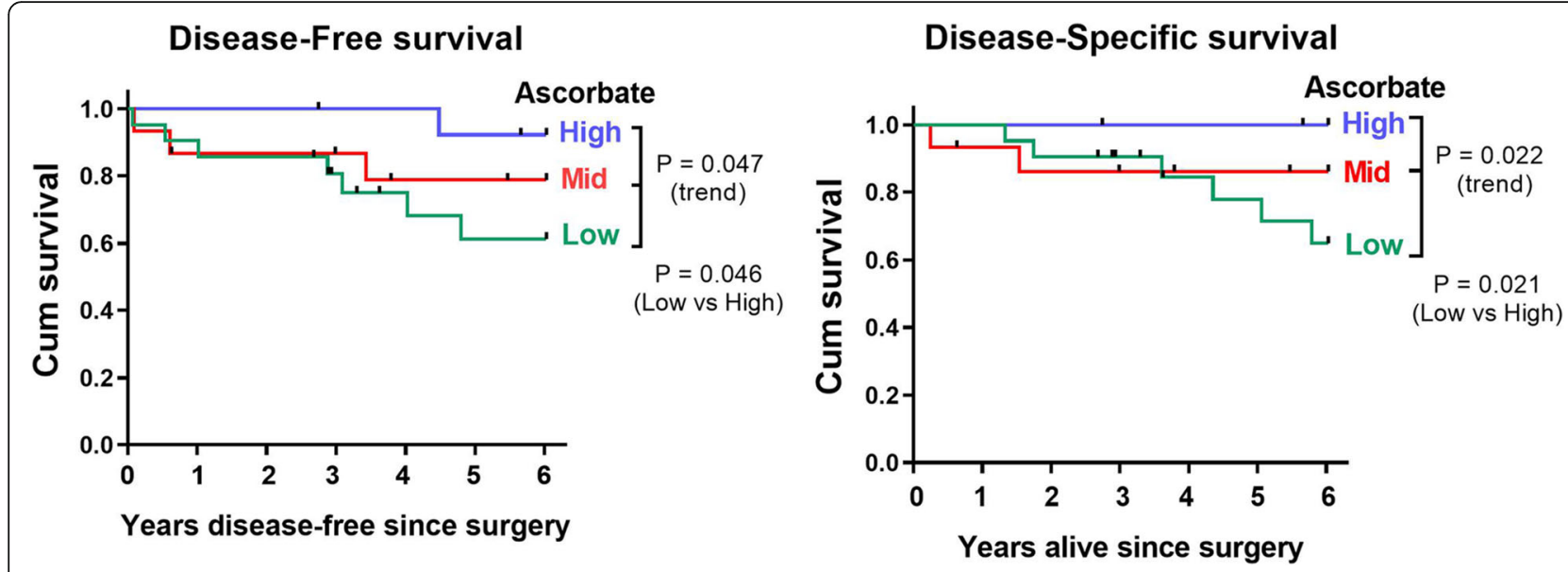

Fig. 5 Tumor ascorbate-associated disease-free and disease-specific 6 year survival. Kaplan Meier 6 year survival curves, plotted with respect to

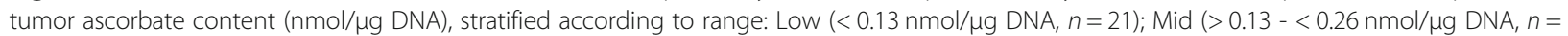
15); High ( $>0.26 \mathrm{nmol} / \mu \mathrm{g}$ DNA, $n=14)$. There was a significant association between tumor ascorbate content and both disease-free and diseasespecific survival. Significance was determined with the logrank (Mantel-Cox) test and three-way ANOVA for trend with increasing ascorbate levels

recent analysis of renal cell carcinomas also provides support for a role for ascorbate as a modulator of HIF-hydroxylase activity. We found no association between ascorbate levels and HIF pathway activation in clear cell renal cell carcinoma, which lacks a functional von Hippel-Lindau (VHL) protein, resulting in constitutive activation of HIF [33]. This contrasted with a clear association between ascorbate content and the HIF pathway observed in papillary renal cell carcinomas with normal VHL and a functional hypoxic response [33].

In addition to ascorbate, low $\mathrm{O}_{2}$ supply and availability of metabolic intermediates will influence HIF-1 activity [1-3]. This is apparent in our results, as a low HIF Pathway score was not confined to samples with high ascorbate levels. This is in agreement with our knowledge that the HIF hydroxylases are inhibited by lack of $\mathrm{O}_{2}, 2$-oxoglutarate or iron [51-53] resulting in the up-regulation of HIF-1. Optimal intracellular availability of oxygen, 2-oxoglutarate and iron, in supporting HIF hydroxylase activity, should help limit HIF-1 activation. Our observation that those tumors with ascorbate levels above the mean had the lowest HIF Pathway scores indicates that increased levels of intracellular ascorbate help optimise HIF-1 hydroxylase activity and could mitigate against HIF-1 activation.

Our study is the first to measure both tumor ascorbate levels and the HIF Pathway in human breast cancer and to demonstrate the potential for moderation of HIF by ascorbate in this disease. Given the importance of HIF-1 as a driver of breast cancer progression [5-9, 11-16], our findings could be of clinical significance and the stratified analysis of disease-free and disease-specific survival underscores this potential.

The tumor ascorbate level varied across a significant range, from $0.002-0.683 \mathrm{nmol} / \mu \mathrm{g}$ DNA. The median was relatively low on this scale $(0.15 \mathrm{nmol} / \mu \mathrm{g}$ DNA), which suggests that ascorbate levels may be compromised in many tumors. Ascorbate is delivered via the vasculature, and when plasma levels are low or when the tissue is poorly perfused, cellular uptake is likely to be limited. Our modelling of ascorbate transport through the tissues has predicted a similar distribution profile for ascorbate as for oxygen [54], reinforcing the potential for a double impact of both oxygen and ascorbate deprivation on the HIF-1 activation. Ascorbate levels in breast tumors were not generally related to normal breast tissue levels, and we found no association between tumor ascorbate levels and expression of SVCT-2, the major ascorbate transporter [55-58]. These findings suggest that numerous factors could affect ascorbate delivery in tumors, with a combined impact of SVCT-2 protein expression and variable plasma supply. SVCT-2 levels were shown to correlate with ascorbate uptake and to influence chemo-sensitivity in breast cancer cells in vitro [59]. Low plasma ascorbate levels have been documented in breast cancer patients, with levels as low as $15 \mu \mathrm{M}$ [60] or $36 \mu \mathrm{M}$ being reported [61-64]. In contrast, plasma levels in the general population average $50 \mu \mathrm{M}$, with levels above $70 \mu \mathrm{M}$ being indicative of plasma saturation [65-68]. The broad range of ascorbate levels in our cohort of breast cancer tissue suggests a complex interplay between tumor vascularity and perfusion, plasma ascorbate availability and variable SVCT-2 expression.

Some recent studies have indicated that plasma levels in excess of $100 \mu \mathrm{M}$ ascorbate are required to overcome the perfusion barrier in tumors [54, 69-72]. Whether this is the case and how best to effectively raise tumor ascorbate levels in order to down-regulate the HIF Pathway are matters for future investigation. Our study suggests that tumor ascorbate levels are an important 
consideration in the effort to mitigate against the detrimental clinical outcome when HIF-1 transcriptional activity is elevated.

\section{Conclusions}

Our retrospective analysis of tumor tissue has determined that tumor ascorbate content is associated with decreased activation of the HIF-1 pathway in human breast cancer. Low levels of HIF-1 activation were strongly indicative of a favourable prognosis and the data suggest that elevated tumor ascorbate levels could moderate the hypoxic response in breast tumors, with a potential clinical benefit. This hypothesis should be tested in future clinical intervention studies.

\section{Abbreviations \\ BNIP-3: BCl-2/adenovirus E1B 19 kDa interacting protein 3; CA-IX: Carbonic- anhydrase IX; CSTB: Cancer Society Tissue Bank; DCIS: Ductal carcinoma in situ; DFS: Disease-free survival; DSS: Disease-specific survival; ER: Oestrogen receptor; Her2: Human epidermal growth factor receptor 2; HIF-1: Hypoxia- inducible factor-1; HR: Hormone receptor; IDC: Invasive ductal carcinoma; PR: Progesterone receptor; SVCT-2: Sodium-dependent vitamin C transporter - 2; VEGF: Vascular endothelial growth factor; VHL: Von Hippel Lindau}

\section{Acknowledgements}

We thank Prof Chris Frampton and Dr. John Pearson for their advice on statistical analysis. We thank Rosie Burn for her analysis of SVCT-2 protein. We acknowledge the Cancer Society Tissue Bank Christchurch for the patient samples used in this study.

\section{Funding}

This study was jointly funded by the New Zealand Breast Cancer Foundation and the Canterbury Medical Research Foundation (Grant number R1512). The funding bodies provided research funds to the University of Otago and were not involved in the study design, data analysis, interpretation of data and in writing the manuscript. GUD was supported by the Mackenzie Charitable Foundation and Genesis Oncology Trust.

\section{Availability of data and materials}

All data generated or analysed during this study are included in this published article, and its supplementary information files. In addition, the datasets used and/or analysed during the current study are available from the corresponding author on reasonable request.

\section{Authors' contributions}

EJC carried out most of the laboratory analyses and analysed the data. HRM is the Tissue Bank Curator who collected and provided the sample information and supervised ethics approvals. VCD retrieved patient survival data. BAR provided clinical oversight of the study and of the data interpretation and edited the manuscript. GUD and MCMV conceived the study, supervised the laboratory analyses, carried out data analysis and cowrote the manuscript. All authors have read and approved the final version of the manuscript.

\section{Ethics approval and consent to participate}

All procedures were in accordance with the University of Otago Human Ethics Committee, New Zealand (H15/093). Tissue samples analysed were collected and stored by the Cancer Society Tissue Bank, Christchurch (CSTB) (Ethical Approval 16STH92). All donors gave written informed consent for sample collection, storage and use, along with their related clinical information. Use of banked samples for this study was approved by the Canterbury Tissue Bank Board (P.15105).

\section{Consent for publication}

Not applicable.

\section{Competing interests}

The authors declare that they have no competing interests.

\section{Publisher's Note}

Springer Nature remains neutral with regard to jurisdictional claims in published maps and institutional affiliations.

\section{Author details}

${ }^{1}$ Mackenzie Cancer Research Group, Department of Pathology and Biomedical Science, University of Otago, Christchurch 8011, New Zealand. ${ }^{2}$ Centre for Free Radical Research, Department of Pathology and Biomedical Science, University of Otago, Christchurch 8140, New Zealand. ${ }^{3}$ Cancer Society Tissue Bank, University of Otago, Christchurch 8011, New Zealand. ${ }^{4}$ Christchurch Breast Cancer Patient Register, Christchurch Hospital, Christchurch 8011, New Zealand. ${ }^{5}$ Canterbury Regional Cancer and Haematology Service, Canterbury District Health Board, Christchurch, and Department of Medicine, University of Otago, Christchurch 8011, New Zealand.

Received: 6 January 2019 Accepted: 21 March 2019

Published online: 03 April 2019

\section{References}

1. Semenza GL. HIF-1: upstream and downstream of cancer metabolism. Curr Opin Genet Dev. 2010;20(1):51-6.

2. Semenza GL. The hypoxic tumor microenvironment: a driving force for breast cancer progression. Biochim Biophys Acta. 2016;1863(3):382-91.

3. Ratcliffe PJ. Oxygen sensing and hypoxia signalling pathways in animals: the implications of physiology for cancer. J Physiol. 2013;591(Pt 8):2027-42.

4. Semenza GL. Regulation of the breast cancer stem cell phenotype by hypoxia-inducible factors. Clin Sci (Lond). 2015;129(12):1037-45.

5. Deb S, Johansson I, Byrne D, Nilsson C, Investigators K, Constable L, Fjallskog ML, Dobrovic A, Hedenfalk I, Fox SB. Nuclear HIF1A expression is strongly prognostic in sporadic but not familial male breast cancer. Mod Pathol. 2014;27(9):1223-30.

6. Li M, Xiao D, Zhang J, Qu H, Yang Y, Yan Y, Liu X, Wang J, Liu L, Wang J, et al. Expression of LPA2 is associated with poor prognosis in human breast cancer and regulates HIF-1alpha expression and breast cancer cell growth. Oncol Rep. 2016;36(6):3479-87.

7. Schoning JP, Monteiro M, Gu W. Drug resistance and cancer stem cells: the shared but distinct roles of hypoxia-inducible factors HIF1alpha and HIF2alpha. Clin Exp Pharmacol Physiol. 2017;44(2):153-61.

8. Vleugel MM, Greijer AE, Shvarts A, van der Groep P, van Berkel M, Aarbodem Y, van Tinteren H, Harris AL, van Diest PJ, van der Wall E. Differential prognostic impact of hypoxia induced and diffuse HIF-1alpha expression in invasive breast cancer. J Clin Pathol. 2005;58(2):172-7.

9. Zhang H, Wong CC, Wei H, Gilkes DM, Korangath P, Chaturvedi P, Schito L, Chen J, Krishnamachary B, Winnard PT Jr, et al. HIF-1-dependent expression of angiopoietin-like 4 and LICAM mediates vascular metastasis of hypoxic breast cancer cells to the lungs. Oncogene. 2012;31(14):1757-70.

10. Cao D, Hou M, Guan YS, Jiang M, Yang Y, Gou HF. Expression of HIF-1alpha and VEGF in colorectal cancer: association with clinical outcomes and prognostic implications. BMC Cancer. 2009;9:432.

11. Volinia S, Galasso M, Sana ME, Wise TF, Palatini J, Huebner K, Croce CM. Breast cancer signatures for invasiveness and prognosis defined by deep sequencing of microRNA. Proc Natl Acad Sci U S A. 2012;109(8):3024-9.

12. Wang T, Gilkes DM, Takano N, Xiang L, Luo W, Bishop CJ, Chaturvedi P, Green JJ, Semenza GL. Hypoxia-inducible factors and RAB22A mediate formation of microvesicles that stimulate breast cancer invasion and metastasis. Proc Natl Acad Sci U S A. 2014;111(31):E3234-42.

13. Wang W, He YF, Sun QK, Wang Y, Han XH, Peng DF, Yao YW, Ji CS, Hu B. Hypoxia-inducible factor 1alpha in breast cancer prognosis. Clin Chim Acta. 2014:428:32-7.

14. Generali D, Berruti A, Brizzi MP, Campo L, Bonardi S, Wigfield S, Bersiga A, Allevi G, Milani M, Aguggini S, et al. Hypoxia-inducible factor-1alpha expression predicts a poor response to primary chemoendocrine therapy and disease-free survival in primary human breast cancer. Clin Cancer Res. 2006;12(15):4562-8.

15. Gilkes DM, Bajpai S, Wong CC, Chaturvedi P, Hubbi ME, Wirtz D, Semenza GL. Procollagen lysyl hydroxylase 2 is essential for hypoxia-induced breast cancer metastasis. Mol Cancer Res. 2013;11(5):456-66. 
16. Gilkes DM, Semenza GL. Role of hypoxia-inducible factors in breast cancer metastasis. Future Oncol. 2013:9(11):1623-36.

17. Landazuri MO, Vara-Vega A, Viton M, Cuevas Y, del Peso L. Analysis of HIFprolyl hydroxylases binding to substrates. Biochem Biophys Res Commun. 2006;351(2):313-20.

18. Peet $\mathrm{D}$, Linke $\mathrm{S}$. Regulation of HIF: asparaginyl hydroxylation. Novartis Found Symp. 2006;272:37-49 discussion 49-53, 131-140.

19. Stolze IP, Mole DR, Ratcliffe PJ. Regulation of HIF: prolyl hydroxylases. Novartis Found Symp. 2006;272:15-25 discussion 25-36.

20. Smirnova NA, Hushpulian DM, Speer RE, Gaisina IN, Ratan RR, Gazaryan IG. Catalytic mechanism and substrate specificity of HIF prolyl hydroxylases. Biochemistry Biokhimiia. 2012;77(10):1108-19.

21. Chowdhury R, Candela-Lena Jl, Chan MC, Greenald DJ, Yeoh KK, Tian YM, McDonough MA, Tumber A, Rose NR, Conejo-Garcia A, et al. Selective small molecule probes for the hypoxia inducible factor (HIF) prolyl hydroxylases. ACS Chem Biol. 2013;8(7):1488-96.

22. Kuiper C, Vissers MC. Ascorbate as a co-factor for Fe- and 2-oxoglutarate dependent dioxygenases: physiological activity in tumor growth and progression. Front Oncol. 2014;4:359.

23. Flashman E, Davies SL, Yeoh KK, Schofield CJ. Investigating the dependence of the hypoxia-inducible factor hydroxylases (factor inhibiting HIF and prolyl hydroxylase domain 2) on ascorbate and other reducing agents. Biochem J. 2010:427(1):135-42.

24. Yeoh KK, Chan MC, Thalhammer A, Demetriades M, Chowdhury R, Tian YM, Stolze I, McNeill LA, Lee MK, Woon EC, et al. Dual-action inhibitors of HIF prolyl hydroxylases that induce binding of a second iron ion. Org Biomol Chem. 2013;11(5):732-45.

25. Kuiper C, Dachs GU, Currie MJ, Vissers MC. Intracellular ascorbate enhances hypoxia-inducible factor (HIF)-hydroxylase activity and preferentially suppresses the HIF-1 transcriptional response. Free Radic Biol Med. 2014;69:308-17.

26. Kuiper C, Dachs GU, Munn D, Currie MJ, Robinson BA, Pearson JF, Vissers $M C$. Increased tumor ascorbate is associated with extended disease-free survival and decreased hypoxia-inducible factor- 1 activation in human colorectal cancer. Front Oncol. 2014:4:10.

27. Kuiper C, Molenaar IG, Dachs GU, Currie MJ, Sykes PH, Vissers MC. Low ascorbate levels are associated with increased hypoxia-inducible factor-1 activity and an aggressive tumor phenotype in endometrial cancer. Cancer Res. 2010;70(14):5749-58

28. Knowles HJ, Raval RR, Harris AL, Ratcliffe PJ. Effect of ascorbate on the activity of hypoxia-inducible factor in cancer cells. Cancer Res. 2003;63(8): 1764-8.

29. Campbell EJ, Vissers MC, Bozonet S, Dyer A, Robinson BA, Dachs GU. Restoring physiological levels of ascorbate slows tumor growth and moderates HIF-1 pathway activity in Gulo(-/-) mice. Cancer Med. 2015;4(2): 303-14.

30. Campbell EJ, Vissers MC, Dachs GU. Ascorbate availability affects tumor implantation-take rate and increases tumor rejection in Gulo-/- mice. Hypoxia. 2016;4:41-52.

31. Vissers MC, Gunningham SP, Morrison MJ, Dachs GU, Currie MJ. Modulation of hypoxia-inducible factor-1 alpha in cultured primary cells by intracellular ascorbate. Free Radic Biol Med. 2007:42(6):765-72.

32. Campbell EJ, Vissers MC, Wohlrab C, Hicks KO, Strother RM, Bozonet SM, Robinson BA, Dachs GU. Pharmacokinetic and anti-cancer properties of high dose ascorbate in solid tumours of ascorbate-dependent mice. Free Radic Biol Med. 2016;99:451-62.

33. Wohlrab C, Vissers MCM, Phillips E, Morrin H, Robinson BA, Dachs GU. The association between ascorbate and the hypoxia-inducible factors in human renal cell carcinoma requires a functional Von Hippel-Lindau protein. Front Oncol. 2018:8:574.

34. Jozwiak P, Krzeslak A, Wieczorek M, Lipinska A. Effect of glucose on GLUT1dependent intracellular ascorbate accumulation and viability of thyroid Cancer cells. Nutr Cancer. 2015;67(8):1333-41.

35. Fitzmaurice C, Allen C, Barber RM, Barregard L, Bhutta ZA, Brenner H, Dicker DJ, Chimed-Orchir O, Dandona R, Dandona L, et al. Global, regional, and National Cancer Incidence, mortality, years of life lost, years lived with disability, and disability-adjusted life-years for 32 Cancer groups, 1990 to 2015: a systematic analysis for the global burden of disease study. JAMA Oncol. 2017;3(4):524-48.

36. Nechuta S, Lu W, Chen Z, Zheng Y, Gu K, Cai H, Zheng W, Shu XO. Vitamin supplement use during breast cancer treatment and survival: a prospective cohort study. Cancer Epidemiol Biomark Prev. 2011;20(2):262-71.
37. Greenlee H, Hershman DL, Jacobson JS. Use of antioxidant supplements during breast cancer treatment: a comprehensive review. Breast Cancer Res Treat. 2009;115(3):437-52.

38. Greenlee H, Kwan ML, Ergas IJ, Sherman KJ, Krathwohl SE, Bonnell C, Lee MM, Kushi LH. Complementary and alternative therapy use before and after breast cancer diagnosis: the pathways study. Breast Cancer Res Treat. 2009; 117(3):653-65.

39. Harris HR, Bergkvist L, Wolk A. Vitamin C intake and breast cancer mortality in a cohort of Swedish women. Br J Cancer. 2013;109(1):257-64.

40. McEligot AJ, Largent J, Ziogas A, Peel D, Anton-Culver H. Dietary fat, fiber, vegetable, and micronutrients are associated with overall survival in postmenopausal women diagnosed with breast cancer. Nutr Cancer. 2006; 55(2):132-40.

41. Poole EM, Shu X, Caan BJ, Flatt SW, Holmes MD, Lu W, Kwan ML, Nechuta SJ, Pierce JP, Chen WY. Postdiagnosis supplement use and breast cancer prognosis in the after breast Cancer pooling project. Breast Cancer Res Treat. 2013;139(2):529-37.

42. Rohan TE, Hiller JE, McMichael AJ. Dietary factors and survival from breast cancer. Nutr Cancer. 1993;20(2):167-77.

43. Larsson SC, Akesson A, Bergkvist L, Wolk A. Multivitamin use and breast cancer incidence in a prospective cohort of Swedish women. Am J Clin Nutr. 2010;91(5):1268-72.

44. Cui Y, Shikany JM, Liu S, Shagufta Y, Rohan TE. Selected antioxidants and risk of hormone receptor-defined invasive breast cancers among postmenopausal women in the Women's Health Initiative observational study. Am J Clin Nutr. 2008;87(4):1009-18.

45. Harris HR, Orsini N, Wolk A. Vitamin C and survival among women with breast cancer: a meta-analysis. Eur J Cancer. 2014;50(7):1223-31.

46. Chen Z, Ai L, Mboge MY, Tu C, McKenna R, Brown KD, Heldermon CD, Frost SC. Differential expression and function of CAIX and CAXII in breast cancer: a comparison between tumorgraft models and cells. PLoS One. 2018;13(7): e0199476.

47. Ivanova L, Zandberga E, Silina K, Kalnina Z, Abols A, Endzelins E, Vendina I, Romanchikova N, Hegmane A, Trapencieris P, et al. Prognostic relevance of carbonic anhydrase IX expression is distinct in various subtypes of breast cancer and its silencing suppresses self-renewal capacity of breast cancer cells. Cancer Chemother Pharmacol. 2015;75(2):235-46.

48. Samanta D, Gilkes DM, Chaturvedi P, Xiang L, Semenza GL. Hypoxiainducible factors are required for chemotherapy resistance of breast cancer stem cells. Proc Natl Acad Sci U S A. 2014;111(50):E5429-38.

49. Harrison H, Rogerson L, Gregson HJ, Brennan KR, Clarke RB, Landberg G. Contrasting hypoxic effects on breast cancer stem cell hierarchy is dependent on ER-alpha status. Cancer Res. 2013;73(4):1420-33.

50. Lachapelle J, Foulkes WD. Triple-negative and basal-like breast cancer: implications for oncologists. Curr Oncol. 2011;18(4):161-4.

51. Ozer A, Bruick RK. Non-heme dioxygenases: cellular sensors and regulators jelly rolled into one? Nat Chem Biol. 2007;3(3):144-53.

52. Hirsila M, Koivunen P, Xu L, Seeley T, Kivirikko Kl, Myllyharju J. Effect of desferrioxamine and metals on the hydroxylases in the oxygen sensing pathway. FASEB J. 2005;19(10):1308-10.

53. Koivunen P, Hirsila M, Gunzler V, Kivirikko Kl, Myllyharju J. Catalytic properties of the asparaginyl hydroxylase $(\mathrm{FIH})$ in the oxygen sensing pathway are distinct from those of its prolyl 4-hydroxylases. J Biol Chem. 2004;279(11):9899-904.

54. Kuiper C, Vissers MC, Hicks KO. Pharmacokinetic modeling of ascorbate diffusion through normal and tumor tissue. Free Radic Biol Med. 2014;77C: $340-52$.

55. Savini I, Rossi A, Pierro C, Avigliano L, Catani MV. SVCT1 and SVCT2: key proteins for vitamin C uptake. Amino Acids. 2008:34(3):347-55.

56. May JM. The SLC23 family of ascorbate transporters: ensuring that you get and keep your daily dose of vitamin C. Br J Pharmacol. 2011;164(7): 1793-801.

57. May JM. Vitamin C transport and its role in the central nervous system. Subcell Biochem. 2012;56:85-103.

58. Nualart F, Mack L, Garcia A, Cisternas P, Bongarzone ER, Heitzer M, Jara N, Martinez F, Ferrada L, Espinoza F, et al. Vitamin C transporters, recycling and the bystander effect in the nervous system: SVCT2 versus gluts. J Stem Cell Res Ther. 2014:4(5):209.

59. Hong SW, Lee SH, Moon JH, Hwang JJ, Kim DE, Ko E, Kim HS, Cho IJ, Kang JS, Kim DJ, et al. SVCT-2 in breast cancer acts as an indicator for L-ascorbate treatment. Oncogene. 2013;32(12):1508-17. 
60. Badid N, Ahmed FZ, Merzouk H, Belbraouet S, Mokhtari N, Merzouk SA, Benhabib R, Hamzaoui D, Narce M. Oxidant/antioxidant status, lipids and hormonal profile in overweight women with breast cancer. Pathol Oncol Res. 2010;16(2):159-67.

61. Nagamma T, Baxi J, Singh PP. Status of oxidative stress and antioxidant levels in smokers with breast cancer from western Nepal. Asian Pac J Cancer Prev. 2014;15(21):9467-70.

62. Shah FD, Patel JB, Shukla SN, Shah PM, Patel PS. Evaluation of plasma nonenzymatic antioxidants in breast cancer etiology. Asian Pac J Cancer Prev. 2009;10(1):91-6.

63. Gerber M, Richardson S, Salkeld R, Chappuis P. Antioxidants in female breast cancer patients. Cancer Investig. 1991;9(4):421-8.

64. Ramaswamy G, Krishnamoorthy L. Serum carotene, vitamin a, and vitamin C levels in breast cancer and cancer of the uterine cervix. Nutr Cancer. 1996; 25(2):173-7.

65. Frei B, Birlouez-Aragon I, Lykkesfeldt J. Authors' perspective: what is the optimum intake of vitamin C in humans? Crit Rev Food Sci Nutr. 2012;52(9): 815-29.

66. Levine M, Conry-Cantilena C, Wang Y, Welch RW, Washko PW, Dhariwal KR, Park JB, Lazarev A, Graumlich JF, King J, et al. Vitamin C pharmacokinetics in healthy volunteers: evidence for a recommended dietary allowance. Proc Natl Acad Sci U S A. 1996:93(8):3704-9.

67. Carr AC, Frei B. Toward a new recommended dietary allowance for vitamin C based on antioxidant and health effects in humans. Am J Clin Nutr. 1999: 69(6):1086-107.

68. Carr AC, Bozonet SM, Pullar JM, Simcock JW, Vissers MC. Human skeletal muscle ascorbate is highly responsive to changes in vitamin $\mathrm{C}$ intake and plasma concentrations. Am J Clin Nutr. 2013:97(4):800-7.

69. Padayatty SJ, Sun H, Wang Y, Riordan HD, Hewitt SM, Katz A, Wesley RA, Levine M. Vitamin C pharmacokinetics: implications for oral and intravenous use. Ann Intern Med. 2004;140(7):533-7.

70. Chen Q, Espey MG, Sun AY, Lee JH, Krishna MC, Shacter E, Choyke PL, Pooput C, Kirk KL, Buettner GR, et al. Ascorbate in pharmacologic concentrations selectively generates ascorbate radical and hydrogen peroxide in extracellular fluid in vivo. Proc Natl Acad Sci U S A. 2007;104(21): 8749-54.

71. Welsh JL, Wagner BA, van't Erve TJ, Zehr PS, Berg DJ, Halfdanarson TR, Yee NS, Bodeker KL, Du J, Roberts $L$ 2nd, et al. Pharmacological ascorbate with gemcitabine for the control of metastatic and node-positive pancreatic cancer (PACMAN): results from a phase I clinical trial. Cancer Chemother Pharmacol. 2013;71(3):765-75.

72. Cieslak JA, Sibenaller ZA, Walsh SA, Ponto LL, Du J, Sunderland JJ, Cullen JJ. Fluorine-18-labeled thymidine positron emission tomography (FLT-PET) as an index of cell proliferation after pharmacological ascorbate-based therapy. Radiat Res. 2016;185(1):31-8.

73. Galea MH, Blamey RW, Elston CE, Ellis IO: The Nottingham Prognostic Index in primary breast cancer. Breast Cancer Research and Treatment. 1992;22(3): 207-219.

74. Kurshumliu F, Gashi-Luci L, Kadare S, Alimehmeti M, Gozalan U: Classification of patients with breast cancer according to Nottingham prognostic index highlights significant differences in immunohistochemical marker expression. World Journal of Surgical Oncology/ 2014;12:243.

\section{Ready to submit your research? Choose BMC and benefit from:}

- fast, convenient online submission

- thorough peer review by experienced researchers in your field

- rapid publication on acceptance

- support for research data, including large and complex data types

- gold Open Access which fosters wider collaboration and increased citations

- maximum visibility for your research: over $100 \mathrm{M}$ website views per year

At $\mathrm{BMC}$, research is always in progress.

Learn more biomedcentral.com/submissions 